\title{
APPLICATION OF TARGETED GOAT GRAZING IN OIL PALM PLANTATIONS: ASSESSMENT OF WEED PREFERENCE, SPATIAL USE OF GRAZING AREA AND LIVE WEIGHT CHANGE
}

\author{
FRISCO NOBILLY ${ }^{1,2^{*}}$; THOMAS MANLIT RAYMOND MAXWELL ${ }^{3}$; MUHAMMAD SYAFIQ YAHYA ${ }^{4}$ and \\ BADRUL AZHAR ${ }^{4,5}$
}

\begin{abstract}
Targeted goat grazing is a promising tool to control competing weeds in crop plantation systems without causing adverse effects on the environment. Here, we investigated the effectiveness of targeted grazing for weed control involving 11 Katjang crossbreed goats in a mature oil palm plantation. We assessed the animal behaviour and management aspects including weed preference, spatial use of grazing area, and body weight change. Asystasia gangetica was the most preferred weed species, followed by Clidemia hirta. Time spent grazing on A. gangetica (45.83-282.91 s) and C. hirta (10.04-49.82 s) by the female goats were different between grazing days $(p<0.05)$. Spatial use between edge and interior areas of grazing plots were not different ( $p=0.718)$, meaning goats grazed evenly throughout the grazing plots. Our results revealed that goats fed evenly on the diverse weed community throughout the grazing plots and maintained similar body weight ( $p=0.488$ ) before and after grazing. Livestock integration with oil palm agriculture in the manner of targeted grazing should be promoted as a part of integrated pest management for reducing weeds. Targeted grazing might be the solution for environmentally sound weed management in sustainable oil palm plantations.
\end{abstract}

Keywords: biological control, integrated pest management, livestock integration, sustainable palm oil.

Received: 28 January 2020; Accepted: 28 September 2021; Published online: 23 November 2021.

\section{INTRODUCTION}

Sustainable palm oil production demands producers to improve current agricultural practices, with

1 Department of Animal Science,

Faculty of Agriculture, Universiti Putra Malaysia,

43400 UPM Serdang, Selangor, Malaysia.

2 Laboratoire d'Excellence (LabEx),

Sustainable Tropical Agriculture and Food Systems,

UPM-Agropolis International Offshore Office,

F-34394 Montpellier CEDEX 5, France.

3 Department of Agricultural Sciences,

Faculty of Agriculture and Life Sciences, Lincoln University,

Lincoln 7647, Christchurch, New Zealand.

4 Department of Forestry Science and Biodiversity,

Faculty of Forestry and Environment,

Universiti Putra Malaysia,

43400 UPM Serdang, Selangor, Malaysia.

5 Biodiversity Unit, Institute of Bioscience,

Universiti Putra Malaysia,

43400 UPM Serdang, Selangor, Malaysia.

* Corresponding author e-mail: frisco@upm.edu.my the intention of compatibility with environmental protection and worker health (Abdul Majid, 2021; Azhar et al., 2017; Saadun et al., 2018;). Palm oil certification schemes such as the Roundtable on Sustainable Palm Oil (RSPO) and Malaysian Sustainable Palm Oil (MSPO) require producers to implement the use of biological control methods in palm oil production (Kalidas, 2012). For instance, biological control such as cover crop management has shown to be effective in reducing weeds and has the potential to be included in sustainably managed oil palm plantations to reduce the use of commercial herbicides (Baumgartner et al., 2008; Gago et al., 2007; Samedani et al., 2015; Tohiran et al., 2019a; 2019b). In Malaysia, leguminous cover crops species commonly used are Pueraria phaseloides (synonym for Pueraria javanica), Centrosema pubescens, Calopogonium mucunoides, C. caeruleum and of late, Mucuna bracteata as they reduce the growth and cover of weed species (Mathews and Saw, 2007). This improvement of agricultural practice is inevitable 
due to the increasing market demand for certified palm oil-based products globally (CPET, 2015). It is forecasted that the scale of oil palm plantation land use will continue to expand in Southeast Asia, Western Africa and South America (Vijay et al., 2016). To date, there is a lack of empirical evidence on biological control as an effective alternative to manage weeds in oil palm plantations.

Weed species such as Chromolaena odorata and Asystasia gangetica are mainly controlled by chemical herbicides in oil palm plantations because they compete with the palm oil crop for water and nutrients, reducing crop health and productivity (Ali et al., 2021; Nchanji et al., 2016; Satriawan et al., 2021; Sidik et al., 2018). Chemical herbicides such as paraquat (600 or $\left.800 \mathrm{~g} \mathrm{ha}^{-1}\right)$, gluphosinateammonium (200 $\left.\mathrm{g} \mathrm{ha}^{-1}\right)$ and glyphosate $\left(400 \mathrm{~g} \mathrm{ha}^{-1}\right)$ are commonly used to control weeds in oil palm plantations (Dilipkumar et al., 2017; Mohamad et al., 2010; Wibawa et al., 2010). Major palm oil producing countries such as Malaysia have banned the use of herbicides such as paraquat (Wibawa et al., 2007), deemed hazardous to human health and the environment (Ferramosca et al., 2021; Pochron et al., 2021; Van Bruggen et al., 2018; Weisenburger, 1993; Zaller et al., 2021). An alternative to using the remaining permitted chemical herbicides for controlling weeds in oil palm plantations is the application of targeted grazing with livestock animals (Tohiran et al., 2017; 2019a; 2019b).

Targeted grazing is grazing by ruminant livestock for a set duration and intensity during a specified stage in the growing season to achieve specific vegetation management goals (Frost and Launchbaugh, 2003; Launchbaugh, 2006; Walker, 1994). It is an under-exploited tool that is fast proving very potent for weed control in expansive rangeland scenarios (Bailey et al., 2019; Frost and Launchbaugh, 2003). Using targeted grazing effectively demands site-specific knowledge of plant growth, animal nutrition, grazing behaviour, ecosystem function and public relations (Macon, 2014). Compared with herbicide application, targeted grazing can be inexpensive, with very light targeted grazing by sheep reducing weeds and increasing desired plant species (Bailey et al., 2019; Rinella and Hileman, 2009).

Goat grazing can be an important tool for biodiversity conservation in agroecosystems if managed appropriately (Azhar et al., 2021; García et al., 2012). The integration of rotationally grazed livestock in oil palm plantations has been promoted in order to manage weeds, supplement crop growth with organic manure, and improve farmland biodiversity (Azhar et al., 2013; Jambari et al., 2012; Tohiran et al., 2017). In established oil palm plantations, noxious weeds such as Asystasia gangetica, Clidemia hirta, Centhotheca lappacea and Cyrtococum accrescens strongly compete with palm oil trees for nutrients, moisture and sunlight and eventually cause yield depression (Azahari et al., 2004). At establishment and early growth stages of palm oil trees, weeds compete for resources, negatively affecting tree growth and yield and obstructing routine estate practices such as harvesting (Azahari et al., 2004; Rosli et al., 2010). Eradication of a very dense stand of $A$. gangetica in an oil palm plantation resulted in a $12 \%$ increase in fresh fruit bunch production (Kustyanti and Horne, 1991). Although the most common costeffective practice to remove oil palm plantation weeds is herbicide application (Wibawa et al., 2010), this method is becoming unfavourable and increasing unpopular with the public due to the toxic and hazardous effects (Farooq et al., 2011). Biological weed control using grazing animals offers an economically cheaper alternative compared to herbicides in crop-livestock integration systems (Sánchez, 1995; Tohiran et al., 2014; 2017).

Feeding behaviour of goats in both open and confined areas influence their diets (Araújo et al., 2018; Goetsch et al., 2010). Previous research has reported that feeding behaviour can be influenced by genotype, environmental conditions (site), differences in vegetation conditions (quality), and preference for different plant species (Goetsch et al., 2010; Mphinyane et al., 2015). However, feeding behaviours of goats raised in the field were almost the same as those raised in a confined area (Silva et al., 2013). Most goat feeding behaviours appear to be influenced by the level of concentrate in the ration ( $\mathrm{Lu}$ et al., 2008) and the physical characteristics of the fibre (Lu et al., 2008; Zhao et al., 2014). Additionally, goat feeding behaviour varies differently with the body size of different genotypes (Koluman et al., 2016).

Animal feeds of natural grass and total mixed rations have different crude fibre content and texture which influence feeding, rumination and chewing activity of goats (Adiwinarti et al., 2019). The more dietary fibre intake by goats, the longer the chewing time required (Lu et al., 2008). Goats fed with high fibre feed needed more time to eat and had longer feeding bouts, causing lower feed intake than goats fed low fibre feed (Adiwinarti et al., 2019). In comparison, goats fed with total mixed rations require more drinking water than goats fed on natural grass (Adiwinarti et al., 2019).

In a grassland environment, grazing has a profound influence on the diversity and spatial distribution of plant species (Adler et al., 2001). Selective grazing of particular species can lead to local extinction or colonisation of plant species, and changes in the within-community spatial organisation of vegetation (Pazos et al., 2007). Additionally, the heterogeneous spatial distribution 
of local disturbances induced by livestock grazing, such as trampling, gap creation, or nutrient deposition, can also create spatial heterogeneity in plant species composition (Adler et al., 2001; Augustine and Frank, 2001). Similar approaches can be applied to crop production, especially in oil palm plantation scenarios. Understanding the spatial distribution of livestock movement around a plantation site can provide significant management tools for farm managers (Sanderson et al., 2010).

Our study assessed the grazing and browsing behaviour and management aspects of targeted goat grazing in an oil palm agro-ecosystem. Specific objectives of the study were: (i) to determine weed preference by local goats (Katjang crossbreed), (ii) determine spatial use of grazing plots by goats, and (iii) measure live weight of goats gain in response to targeted grazing on understory weeds. This study sheds new light on the application of grazing livestock as a potential biological weed control method in sustainable palm oil production.

\section{MATERIALS AND METHODS}

\section{Study Site}

This single livestock species grazing study was conducted at the Malaysian Palm Oil Board (MPOB) Keratong Research Station, Pahang, Malaysia (N 02'47'56.1" E 102'55'37.6") between July and August 2016. The research station is located in a 700 ha oil palm plantation, with a planting density of 136 palms per ha. The oil palm stand was 17 years old. Weed control using chemical herbicide is sprayed three to four times per year and has been the standard practice for more than 25 years.

\section{Experimental Design and Animals}

Seven, $25 \mathrm{~m} \times 25 \mathrm{~m}$ randomly allocated grazing plots within the 700 ha plantation were erected using portable net-type electric fences, powered by 12 volt rechargeable lead battery. Individual grazing plots were divided into three rectangular strips $(8.3 \mathrm{~m} \times 25 \mathrm{~m})$ with each strip allocated for one day of grazing. The grazing plots were characterised by a flat area of nine oil palm trees. A total of 11 healthy Katjang crossbreed (Capra hircus) goats, comprising one buck and 10 does, aged between 12 to 24 months were used in this study. The goats were fed with commercial pellets (soybean hull) and oil palm fronds leaves before the grazing commenced. Each individual goat was ear tagged for identification. Goats were released from their shelter and herded to their allocated sub-plot at $10.00 \mathrm{am}$ and then herded back to their shelter at 2.00 pm daily (approximately $4 \mathrm{hr}$ of grazing daily). Each goat was supplemented with $200 \mathrm{~g}$ soybean hull pellets and ad libitum supply of chopped palm oil fronds, after returning to their shelter. Goats were allowed to graze in each grazing sub-plot for one day before moving to an adjacent plot. Each goat was first weighed prior to grazing and re-weighed every seven days using a portable digital weighing scale. The mean initial doe body weight was $17.67 \mathrm{~kg}$, while the buck was $31.40 \mathrm{~kg}$. Prior to commencement of the targeted grazing experiment, goats were trained to familiarise with the live electric fencing. During the study period, the grazing plot areas were not sprayed with herbicides. Out of the 11 animals used in this study, unfortunately three had died due to parasite infection.

\section{Goat Grazing Preference for Weed Species}

We used scan sampling to randomly select seven individual goats and recorded the types of weed species they selected during a 15-min browsing bout. We used a digital stopwatch to record the duration of time spent browsing a particular weed species. This 15-min duration was counted as a visual observation. In this study, we recorded a total of 147 visual observations.

\section{Spatial Use of Grazing Plot}

At 15-min intervals, we determined the specific location of each goat, either at the edge (within $5 \mathrm{~m}$ from the fence) or at the interior (beyond $5 \mathrm{~m}$ of the fence) of the grazing plot. This 15-min interval was counted as a visual observation adapted from Parsons and Dumont (2003). A total of 378 visual observations were recorded.

\section{Data Analysis}

Prior to data analyses, Shapiro-Wilk's tests were performed to determine the distribution pattern of collected data. To improve the linearity of data distribution, data was either square root or log transformed. To compare the number of weed species browsed by different individual animals and grazing days (day 1-21), we performed a balanced one-way analysis of variance (ANOVA). We used post hoc analysis (i.e., Tukey's test) to conduct multiple comparisons of different treatment (grazing day) levels. To compare the grazing time between different spatial areas (edge or interior of grazing plot), we conducted an unbalanced one-way ANOVA. To compare the body weight of does, we performed a balanced one-way ANOVA and post hoc analysis (i.e., Tukey's test). The buck was excluded from the data analyses. We performed all statistical analyses in GenStat version 15 (VSNI, Hemel Hempstead United Kingdom). 


\section{RESULTS AND DISCUSSION}

\section{Weed Preference and Control}

Thirteen weed species were grazed and browsed by goats (Table 1). Within each grazing plot, the weed cover was completely cleared after three days of grazing (Figure 1). There was no significant difference in the number of browsed weed species between the seven different individual goats $(\mathrm{df}=6$; variance ratio $=0.75 ; p=0.607 ;$ Figure 2 ). This result indicates that each doe was consistent with respect to the number of weed species that it could control in oil palm plantations. However, there was a significant difference in the number of weed species browsed by goats between different days $(\mathrm{df}=20$; variance ratio $=2.29 ; p=0.003$; Figure 3 ).

Based on the cumulative data of time spent grazing, Asystasia gangetica was the most preferred weed species during the first day at each grazing plot, followed by Clidemia hirta (Table 1). There was a significant difference in time spent grazing A. gangetica $(\mathrm{df}=6$; variance ratio $=5.86 ; p<0.001)$ and $C$. hirta $(\mathrm{df}=6$; variance ratio $=2.29 ; p=0.039)$ between the seven individual female goats (Figure 3). Similarly, time spent grazing A. gangetica $(\mathrm{df}=20$; variance ratio $=5.21 ; p<0.001)$ and $C$. hirta $(\mathrm{df}=20$; variance ratio $=5.28 ; p<0.001)$ by the female goats was different between grazing days (Figure 3 ). Our results show that time spent browsing on Centhotheca lappacea $(\mathrm{df}=20$; variance ratio $=5.29$; $p<0.001)$ and Ischaemacum muticum $(\mathrm{df}=20$; variance ratio=1.95; $p=0.014)$ was significantly different between days (Figure 3).

Time spent grazing Cyrtococum accrescens was not significantly different between the seven individual does, nor between the grazing days (Figure 3). There was also no significant difference in time spent grazing C. lappacea and I. musticum between the seven individual does (Figure 3).

TABLE 1. CHECKLIST OF WEED SPECIES GRAZED BY GOATS IN AN OIL PALM PLANTATION

\begin{tabular}{|c|c|c|c|c|}
\hline Species & Family & Growth habit & Duration & $\begin{array}{c}\text { Cumulative time spent on } \\
\text { feeding by goats (s) }\end{array}$ \\
\hline Asystasia gangetica & Acanthaceae & Forb/herb & Perennial & 31054 \\
\hline Clidemia hirta & Melastomataceae & Shrub & Perennial & 7171 \\
\hline Centotheca lappacea & Poaceae & Graminoid & Perennial & 3558 \\
\hline Cyrtococum accrescens & Poaceae & Graminoid & Annual & 2518 \\
\hline Ischaemum muticum & Poaceae & Graminoid & Perennial & 1410 \\
\hline Stenochlaena palustris & Blechnacea & Forb/herb & Perennial & 250 \\
\hline Chromolaena odorata & Asteraceae & Shrub & Perennial & 185 \\
\hline Nephrolepis biserrata & Lomariopsidaceae & Forb/herb & Perennial & 96 \\
\hline Davallia denticulata & Davalliaceae & Forb/herb & Perennial & 84 \\
\hline Adiantum latifolium & Pteridaceae & Forb/herb & Perennial & 75 \\
\hline Vittaria elongata & Pteridaceae & Forb/herb & Perennial & 46 \\
\hline Paspalum dilatum & Poaceae & Graminoid & Perennial & 3 \\
\hline Paspalum conjugatum & Poaceae & Graminoid & Perennial & 1 \\
\hline
\end{tabular}

(a)
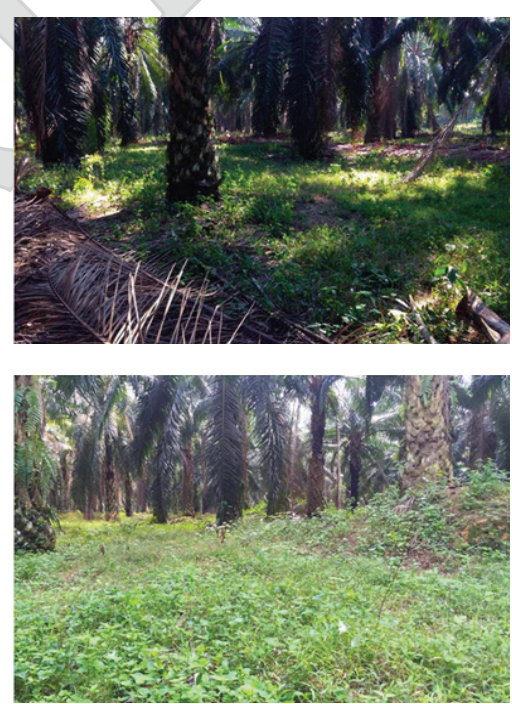

(b)


Figure 1. (a) Weed cover in oil palm plantations before, and (b) after targeted goat grazing over three days. 

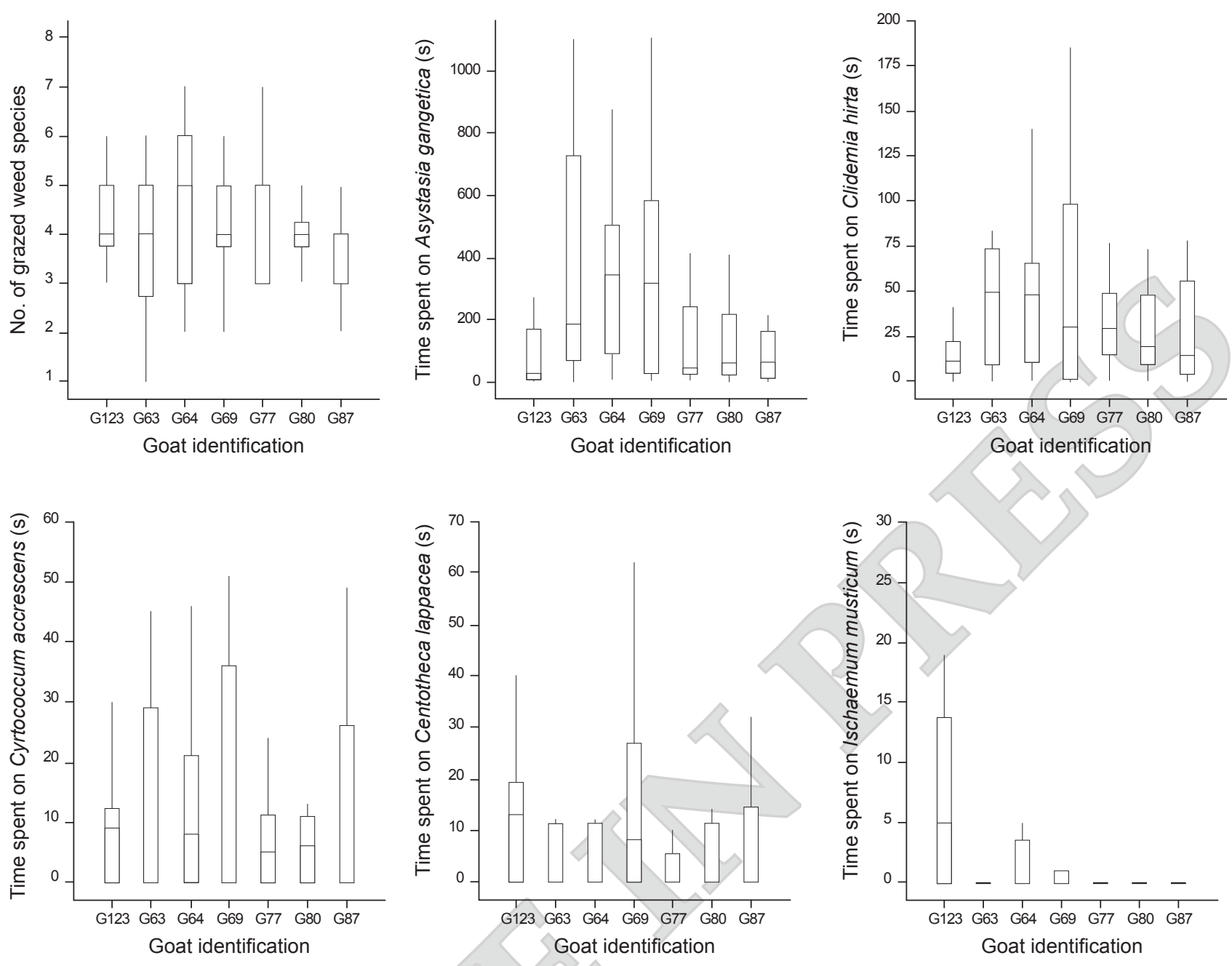

Figure 2. Boxplots of the number of weed species grazed, and top five weed species preferred by goats with respect to individual animals grazing time within grazing plots in an oil palm plantation.

\section{Spatial Use of Grazing Plots}

No significant difference in spatial use between edge and interior areas of grazing plots was observed $(\mathrm{df}=1$; variance ratio $=0.13 ; p=0.718)$. The goats grazed evenly throughout the grazing plots without displaying spatial bias towards the edge or interior areas. In addition, grazing days had no significant effect on spatial $\mathrm{use}(\mathrm{df}=2$; variance ratio $=1.04 ; p=0.355)$.

\section{Live Body Weight Gain}

There was no significant difference in body weight, before and after grazing, among the 10 does $(\mathrm{df}=4$; variance ratio $=0.87 ; p=0.488$; Figure 4$)$. Our data indicate that the body weights decreased in the first week ( $\bar{\chi}=16.82 \mathrm{~kg}$; day 7$)$ and second week $(\bar{\chi}=17.19 \mathrm{~kg}$; day 14$)$, but gradually increased in the third week ( $\bar{\chi}=17.83 \mathrm{~kg}$; day 21$)$ and fourth week $(\bar{\chi}=18.25 \mathrm{~kg}$; day 28 ; Figure 4$)$.

\section{Goat Preferences for Weed Species}

Our data indicate Katjang crossbreed goats consume ground level weeds, but they also browse taller and woodier vegetation. As efficient browsers, goats have a unique character that distinguishes them from almost all other types of livestock. Browsing makes up approximately $60 \%$ of a goat's activity but only about $10 \%-15 \%$ of a cow's activity (Bull, 2000). In oil palm plantations, prevalent weeds species such as A. gangetica, C. hirta and C. odorata are readily available and have become the common plant species of the understory ground layer of Malaysian oil palm plantations (Wibawa et al., 2009). This study suggests that these three weed species have lower fibre content. Goats prefer to browse weed species with greater palatability and lower fibre content (Nampanzira et al., 2015), with A. gangetica being the most preferred species (Achonwa et al., 2017). 

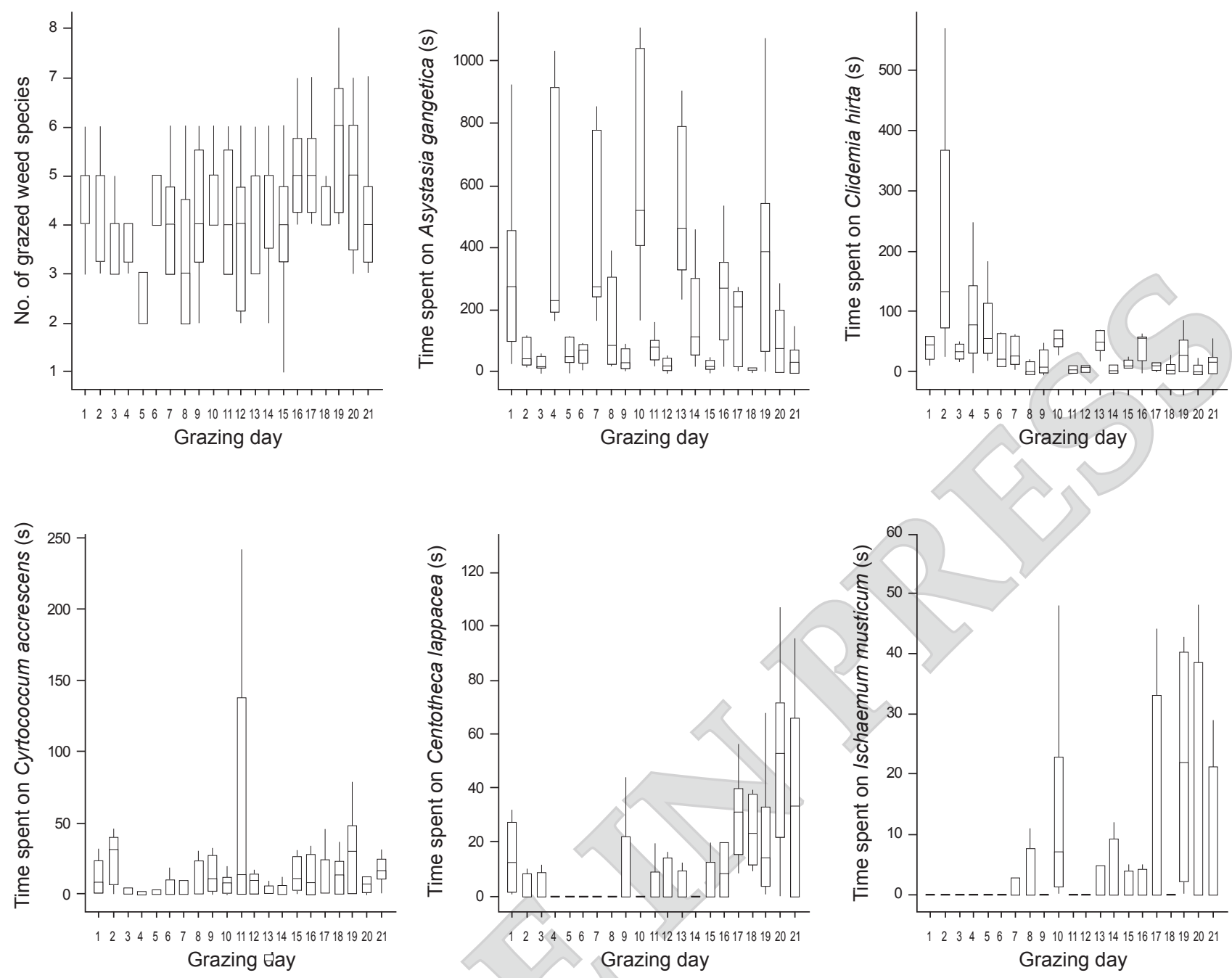

Figure 3. Boxplots of the number of weed species and top five weed species preferred by goats with respect to grazing day in an oil palm plantation.

(a)

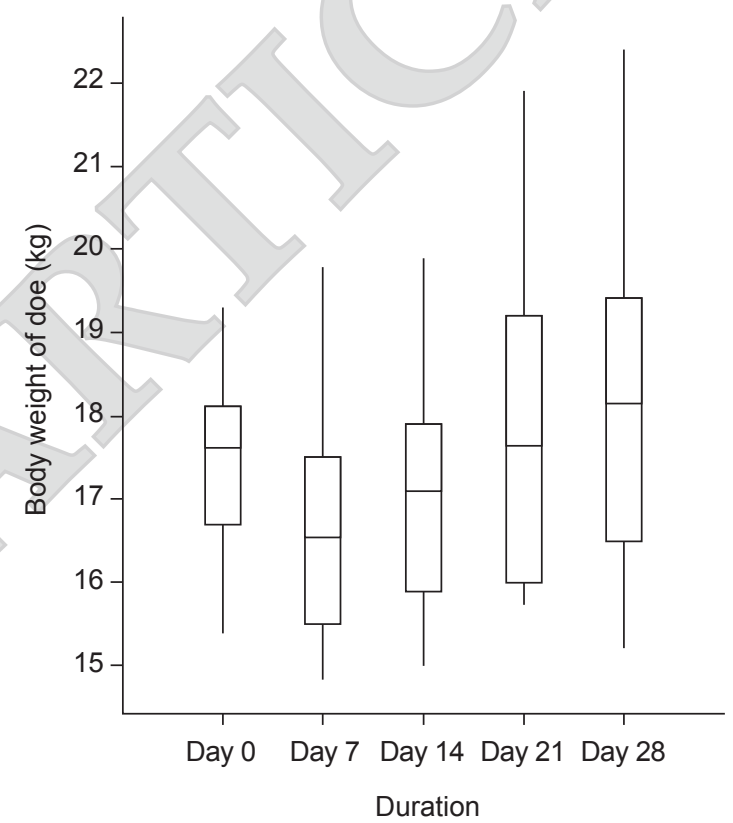

(b)

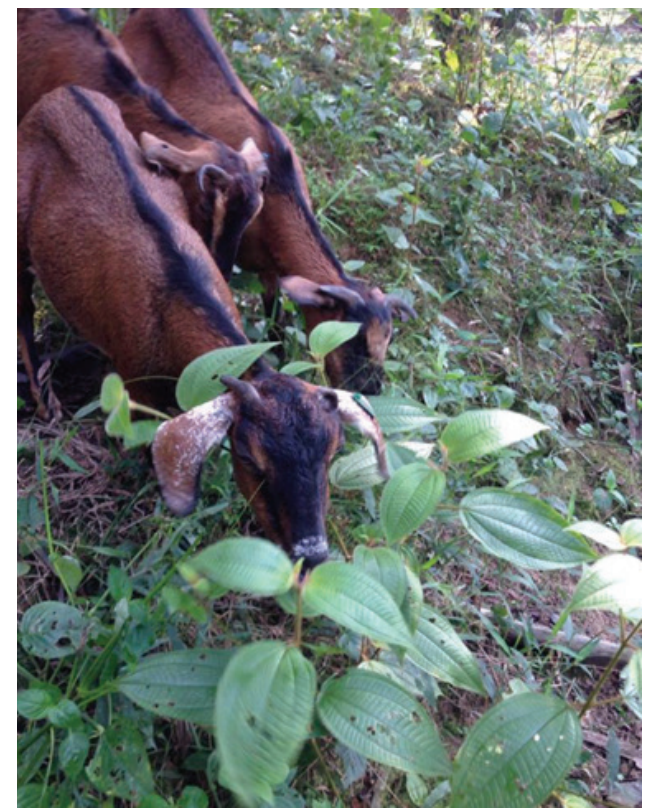

Figure 4. (a) Goat performance during the implementation of targeted grazing. (b) Goats browse weeds that would be conventionally controlled by herbicides in oil palm plantations. 
Understanding goat grazing behaviour in oil palm plantation areas is important knowledge for a plantation's manager if they wish to practice targeted grazing for weed control as an alternative to herbicide application. Goats and sheep have been shown to graze or browse in cyclic patterns, devouring substantial amounts of weed species during one grazing period, followed by low weed consumption in the following period (Launchbaugh et al., 2006). Our results indicate that goat selection was consistent across all scales which is consistent to the finding of Skarpe et al. (2007). Of the weed species present, goats selected to browse from relatively high trees and from trees with signs of previous browsing which is also consistent with Skarpe et al., 2007. Goats are known to be agile compared with cattle and sheep, frequently using a bipedal stance and climbing to gain access to vegetation of interest (Animut and Goetsch, 2008).

Goats prefer to browse several plant species that are considered weeds in typical oil palm plantation, e.g., C. hirta and C. odorata. In addition, goats are known for their consumption of seeds and reproductive stems, and the ability to decrease spread of some undesirable plant species (Animut and Goetsch, 2008). By using goats, control of unwanted weed species in oil palm plantations can be achieved via frequent defoliation of the undesirable species, removal of active growing points, and at high and frequent enough intensities to deplete root energy reserves. However, this may require standard or even higher stocking rates (Gabdo and Abdlatif, 2013).

The first objective of the study was to investigate weed species preferences by local Katjang crossbreed goats as a potential management practice to control weeds in the oil palm plantation. In our study, most of the weeds selected by goats were as nutritious as some common grass species available at the plantation i.e., Centotheca lappacea, Cyrtococum accrescens and Paspalum dilatum (Gibson, 2009). Careful planning for utilising the weeds will produce reasonable goat performance. It is reasonable to maintain and leave some weed cover for the next defoliation. Appropriate utilisation of the weeds so as not to kill them may result in underutilisation of the weeds biomass, due to goat browsing preferences.

\section{Spatial Use of Grazing Plots}

Our findings highlight that targeted goat grazing controls weed cover consistently throughout the grazing plots. It also indicates that goats are an effective biological control agent for weeds in an oil palm plantation and that portable net electric fencing is indispensable in managing the movement of goats during grazing. The stocking density (i.e., approximately $5 \mathrm{~m}^{2}$ per goat per hr) is sufficient to clear the weeds in oil palm plantation. High stocking density stimulates feeding behaviours that increase utilisation of weed biomass by goats (Utsumi et al., 2010).

\section{Goat Performance}

The goats used in this study did not show an overall increase in body weight. The goats lost weight in the first half of the experiment and regained body weight again in the latter half of the grazing period. Our results indicate that goats can browse on weeds in oil palm plantations, without a severe decrease in live weight gain. Goat's live weight gain may be improved by adjusting stocking rates and the intensity and frequency of defoliation of the target weed species. The information gained here from the first objective, that goats show higher browsing preferences for the most prevalent weed species, which can help to refine future studies on managing goat browsing of weeds to achieve live weight gain targets as well as desired weed control.

Common weed plants in oil palm plantations can provide high forage value for livestock (Tohiran et al., 2014; 2017; 2019a; 2019b). The leaves and parts of woody plants browsed by the goats in oil palm plantations can be highly nutritious (Tohiran et al., 2014). Animal body weight indicates the type and amount of vegetation present (Launchbaugh et al., 2006). Hence, goat performance depends on stocking density allowing for selection of most nutritious weeds, grazing time, and on the level of supplementary stall feeding.

\section{Future of Targeted Grazing for Weed Management}

Targeted goat grazing practice is an environmentally sound method for controlling weeds in mature (i.e., more than five years) oil palm plantations. Moreover, this practice of using livestock grazing or browsing for short periods at high intensity can reduce the presence of pest plants (Launchbaugh et al., 2006). This agricultural practice, which integrates commodity crop and livestock production, inclines toward integrated pest management and reduced synthetic herbicide inputs. Our study revealed that goats fed on a diverse weed community, grazed weeds evenly throughout the grazing plots, and overall maintained similar body weight over the course of grazing in the plantation. This can address a number of the criteria for sustainability defined by the MSPO and other palm oil certification schemes (e.g., the RSPO). These include safe (or reduced) use of agrochemicals to protect human health and the environment, and application of integrated pest management systems to control weeds. In addition, oil palm-livestock integration practice in 
the manner of targeted grazing is compatible with the United Nations Sustainable Development Goals (SDGs).

Targeted grazing can be used to accomplish vegetation management goals (e.g., lowered costs for management weed control (Frost et al., 2012). As such, targeted grazing is being rediscovered as a viable and chemical-free tool to control weeds in Southeast Asia (Tohiran et al., 2014; 2019b) which can be practically applied for sustainable palm oil production and enhanced biodiversity conservation in conventional oil palm agriculture (Tohiran et al., 2017; 2019a; 2019b). Further experiments are required to optimise the application of targeted grazing in oil palm plantations. These may include studies on vegetation structure and composition, soil compaction, multiple stocking density and grazer species/breeds, organic carbon level in soil, and wider ecological impacts (Launchbaugh et al., 2006).

\section{CONCLUSION}

The application of targeted goat grazing to control weeds in oil palm plantations can be agriculturally effective. Our study shows that targetted grazing with livestock can be as effective as herbices application in palm oil plantation (Tohiran et al., 2017). We recommend the floristic composition of weeds and ground coverage area to be measured in the future, in order to estimate the stocking density of the animal for weed control application. Livestock integration with oil palm agriculture in the manner of targeted grazing should be promoted as a part of integrated pest management to manage weeds.

\section{ACKNOWLEDGEMENT}

We thank Mr. Muhammad Normustaqhim Mohd Nayan, Ms. Nurul Syahirah Zaki, Ms. Nur Fatin Nabilah Miskan, Mr. Ahmad Izzat Fauzan Sahim and Mr. Mohd Fathil Kamel for assisting us in the field. We are also grateful to the Director-General of the MPOB and the Director of Smallholder Development Research Division of MPOB, Raja Zulkifli Raja Omar and his team members; Dr. Kamil Azmi Tohiran and Dr. Md Zainal Rasyidi Mat Rodi for the support and cooperation.

\section{REFERENCES}

Abdul Majid, N; Ramli, Z; Md Sum, S and Awang, A $H$ (2021). Sustainable palm oil certification scheme frameworks and impacts: A systematic literature review. Sustainability, 13(6): 3263.
Achonwa, C C; Ogbuewu, I P; Ogundu, E C; Kubkomawa, I H; Uchegbu, M C and Okoli, I C (2017). Browse abundance and the methodologies for their selection as candidate feed resources in Nigeria: A review. Nat. Sci., 15(5): 82-94.

Adiwinarti, R; Lestari, C M S and Purnomoadi, A (2019). Feeding behaviour and drinking activities of Kacang goat fed high and low fibre diets. IOP Conf. Ser.: Earth Environ. Sci., 247(1). 012020.

Adler, P; Raff, D and Lauenroth, W (2001). The effect of grazing on the spatial heterogeneity of vegetation. Oecologia, 128: 465-479.

Ali, N B M; Karim, M F A; Saharizan, N; Adnan, N S; Mazri, N H; Fikri, N A; Amaludin, N A and Zakaria, R (2021). Weeds diversity in oil palm plantation at Segamat, Johor. IOP Conf. Ser.: Earth Environ. Sci., 756(1): 012034.

Animut, G and Goetsch, A L (2008). Co-grazing of sheep and goats: Benefits and constraints. Small Rumin. Res., 77(2): 127-145.

Araújo, R A; Neiva, J N M; Pompeu, R C F F; Cândido, M J D; Rogério, M C P; Lucas, R C; Maranhão, S R; Fontinele, R G and Egito, A S (2018). Feeding behavior and physiological parameters of rearing goats fed diets containing detoxified castor cake. Semin. Ciênc. Agrár., 39(5): 2247-2260.

Augustine, D J and Frank, D A (2001). Effects of migratory grazers on spatial heterogeneity of soil nitrogen properties in a grassland ecosystem. Ecology, 82: 3149-3162.

Azhar, B; Sapari, M; Zulkifly, S; Suhailan, W M and Sajap, A S (2013). Protecting biodiversity outside natural forests: Environmental friendly oil palm plantations as an off-reserve strategy in Peninsular Malaysia. Pertanika J. Trop. Agric. Sci., 36(S): 231-246.

Azhar, B; Saadun, N; Prideaux, M and Lindenmayer, D B (2017). The global palm oil sector must change to save biodiversity and improve food security in the tropics. J. Environ. Manage., 203: 457-466.

Azhar, B; Nobilly, F; Lechner, A M; Tohiran, K A; Maxwell, T M R; Zulkifli, R; Kamel, M F and Oon, A (2021). Mitigating the risks of indirect land use change (ILUC) related deforestation from industrial palm oil expansion by sharing land access with displaced crop and cattle farmers. Land Use Policy, 107: 105498.

Azahari, M; Samingin, I and Seman, I A (2004). Weed management. Oil Palm Cultivation in Malaysia (Ghani, E A; Zakaria, Z Z and Wahid, M B eds.). MPOB, Bangi. 
Bailey, D W; Mosley, J C; Estell, R E; Cibils, A F; Horney, M; Hendrickson, J R; Walker, J W; Launchbaugh, K L and Burritt, E A (2019). Synthesis paper: Targeted livestock grazing: Prescription for healthy rangelands. Rangel. Ecol. Manag., 72(6): 865877.

Baumgartner, K; Steenwerth, K L and Veilleux, L (2008). Cover-crop systems affect weed communities in a California vineyard. Weed Sci., 56: 596-605.

Bull, B (2000). Using goats for vegetation management. Nobel news and views. https:// www.noble.org / news / publications / ag-news-andviews / 2000/ september / using-goats-for-vegetationmanagement, accessed on 12 December 2018.

CPET (2015). UK consumption of sustainable palm oil. CPET Annual review of UK palm oil consumption 2015. https://assets.publishing. service.gov.uk/government/uploads / system / uploads / attachment_data/file/477236/cpetannual-review-consumption-palm-oil-2015, accessed on 12 December 2018.

Dilipkumar, M; Chuah, T S; Goh, S S and Sahid, I (2017). Weed management issues, challenges and opportunities in Malaysia. Crop Prot., 134: 104347.

Farooq, M; Jabran, K; Cheema, Z A; Wahid, A and Siddique, K H M (2011). The role of allelopathy in agricultural pest management. Pest. Manag. Sci., 67: 494-506.

Ferramosca, A; Lorenzetti, S; Di Giacomo, M; Murrieri, F; Coppola, L and Zara, V (2021). Herbicides glyphosate and glufosinate ammonium negatively affect human sperm mitochondria respiration efficiency. Reprod. Toxicol., 99: 48-55.

Frost, R A and Launchbaugh, KL (2003). Prescription grazing for rangeland weed management: A new look at an old tool. Rangelands, 25: 43-47.

Frost, R; Walker, J; Madsen, C; Holes, R; Lehfeldt, J; Cunningham, J; Voth, K; Welling, B; Davis, T Z; Bradford, D; Malot, J and Sullivan, J (2012). Targeted grazing: Applying the research to the land. Rangelands, 34: 2-10.

Gabdo, B and Abdlatif, I B (2013). Analysis of the benefits of livestock to oil palm in an integrated system: Evidence from selected districts in Johor, Malaysia. J. Agric. Sci., 5: 47-55.

Gago, P; Cabaleiro, C and Garcia, J (2007). Preliminary study of the effect of soil management systems on the adventitious flora of a vineyard in North-Western Spain. Crop Prot., 26: 584-591.
García, R R; Celaya, R; García, U and Osoro, K (2012). Goat grazing, its interactions with other herbivores and biodiversity conservation issues. Small Ruminant Res., 107(2): 49-64.

Gibson, D J (2009). Grasses and Grassland Ecology. Oxford University Press Inc. New York.

Goetsch, A L; Gipson, T A; Askar, A R and Puchala, $\mathrm{R}$ (2010). Invited review: Feeding behavior of goats'. J. Anim. Sci., 88(1): 361-373.

Jambari, A; Azhar, B; Ibrahim, N L; Jamian, S; Hussin, A; Puan, C L; Mohd Noor, H; Yusof, E and Zakaria, M (2012). Avian biodiversity and conservation in Malaysian oil palm production areas. J. Oil Palm Res., 24: 1277-1286.

Kalidas, P (2012). Pest problems of oil palm and management strategies for sustainability. Agrotechnol., S11. DOI: 10.4172 / 2168-9881.S11-002.

Koluman, N; Boga, M; Silanikove, N and Gorgulu, $M$ (2016). Performance and eating behaviour of crossbred goats in Mediterranean climate of Turkey. Rev. Bras. de Zootec., 45(12): 768-772. DOI: 10.1590/ s1806-92902016001200006.

Kustyanti, T and Horne, P (1991). The effect of Asystasia on the growth of young rubber in polybags. http: / / pdf.usaid.gov / pdf_docs / PDABG454.pdf., accessed on 12 January 2017.

Launchbaugh, K; Walker, J and Daines, R L (2006). Targeted grazing: A natural approach to vegetation management and landscape enhancement. American Sheep Industry Association, Englewood, Colorado, USA.

Lu, C D; Kawas, J R and Mahgoub, O G (2008). Review: Recent advancements in fibre digestion and utilization in goats. Trop. Subtrop. Agroecosystems, 9: 65-72.

Macon, D (2014). The art and science of targeted grazing - A producer's perspective. Rangelands, 36(5): 31-35.

Mathews, J and Saw, E K (2007). IOI's experiences with establishing Mucuna bracteata on soil derived. Mucuna bracteata (Goh, K J and Chiu, S B eds.). Agricultural Crop Trust (ACT), Petaling Jaya. Malaysia.

Mohamad, R; Wibawa, W; Mohayidin, M G; Puteh, A; Juraimi, A S; Awang, Y and Mohd Lassim, M (2010). Management of mixed weeds in young oilpalm plantation with selected broad-spectrum herbicides. Pertanika J. Trop. Agric. Sci., 33(2): 193-203. 
Mphinyane, W N; Tacheba, G and Makore, J (2015). Seasonal diet preference of cattle, sheep and goats grazing on the communal grazing rangeland in the Central District of Botswana. Afr. J. Agric. Res., 10(29): 2791-2803.

Nampanzira, D K; Kabasa, J D; Nalule, S A; Nakalembe, I and Tabuti, J R S (2015). Characterization of the goat feeding system among rural small holder farmers in the semi-arid regions of Uganda. SpringerPlus, 4(1): 188.

Nchanji, Y K; Nkongho, R N; Mala, W A and Levang, $P$ (2016). Efficacy of oil palm intercropping by smallholders. Case study in South-West Cameroon. Agroforest. Syst., 90: 509-519.

Parsons, A J and Dumont, B (2003). Spatial heterogeneity and grazing processes. Anim. Res., 52: 161-179.

Pazos, G E; Bisigato, A J and Bertiller, M B (2007). Abundance and spatial patterning of coexisting perennial grasses in grazed shrublands of the Patagonian Monte. J. Arid Environ., 70: 316-328.

Pochron, S T; Mirza, A; Mezic, M; Chung, E; Ezedum, Z; Geraci, G; Mari, J; Meiselbach, C; Shamberger, O; Smith, R; Tucker, W J and Zafar, S (2021). Earthworms Eisenia fetida recover from Roundup exposure. Appl. Soil Ecol., 158: 103793.

Rinella, M J and Hileman, B J (2009). Efficacy of prescribed grazing depends on timing intensity and frequency. J. Appl. Ecol., 46(4): 796-803.

Rosli, B M; Wibawa, W; Mohayidin, M G; Puteh, A B; Juraimi, A S; Awang, Y and Lassim, M B M (2010). Management of mixed weeds in young oil-palm plantation with selected broad-spectrum herbicides. Pertanika J. Trop. Agr. Sci., 33: 193-203.

Saadun, N; Lim, E A L; Esa, S M; Ngu, F; Awang, F; Gimin, A; Johari, I H; Firdaus, M A; Wagimin, N I and Azhar, B (2018). Socio-ecological perspectives of engaging smallholders in environmental-friendly palm oil certification schemes. Land Use Policy, 72: 333-340.

Samedani, B; Juraimi, A S; Rafii, M Y; Awadz, S S; Anwar, M P and Anuar, A R (2015). Effect of cover crops on weed suppression in oil palm plantation. Int. J. Agric. Biol., 17: 251-260.

Sánchez, M (1995). Integration of livestock with perennial crops. World Animal Review, 82(1): 50-57.

Sanderson, M A; Feldmann, C; Schmidt, J; Hermann, A and Taube, F (2010). Spatial distribution of livestock concentration areas and soil nutrients in pastures. J. Soil Water Conserv., 65: 180-189.

Satriawan, H; Fuady, Z and Fitri, R (2021). Physical and chemical properties of oil palm land which overgrown with weeds at different plant age. IOP Conf. Ser.: Earth Environ. Sci., 749(1). p. 012014.

Sidik, S; Purba, E and Yakub, E N (2018). Population dynamics of weeds in oil palm (Elaeis guineensis Jacq.) circle weeding area affected by herbicide application. IOP Conf. Ser.: Earth Environ. Sci., 122(1). p. 012069.

Silva, C M; Furtado, D A; Medeiros, A N; Saraiva, E P; Guimaraes, M C C; Tota, L C A and Lopes, K B $P$ (2013). Ethogram of three genetic groups of goats confined using monitoring video images. Rev. Etol., 12(1-2): 1-11.

Skarpe, C; Jansson, I; Seljeli, L; Bergström, R and Røskaft, E (2007). Browsing by goats on three spatial scales in a semi-arid savanna. J. Arid Environ., 68(3): 480-491.

Tohiran, K A; Omar, R Z; Khasim, N; Rodi, M Z; Basri, N K and Omar, W (2014). Transforming oil palm plantation for forage and livestock integration. Oil Palm Bulletin, 69: 1-4.

Tohiran, K A; Nobilly, F; Zulkifli, R; Maxwell, T; Moslim, R and Azhar, B (2017). Targeted cattle grazing as an alternative to herbicides for controlling weeds in bird-friendly oil palm plantations. Agron. Sustain. Dev., 37: 62.

Tohiran, K A; Nobilly, F; Maxwell, T; Puan, C L; Zakaria, M; Zulkifli, R; Ashton-Butt, A and Azhar, B (2019a). Cattle grazing benefits farmland bird community composition in oil palm plantations. Ornithol. Sci., 18(1): 81-94.

Tohiran, K A; Nobilly, F; Zulkifli, R; Ashton-Butt, A and Azhar, B (2019b). Cattle-grazing in oil palm plantations sustainably controls understory vegetation. Agric. Ecosyst. Environ., 278: 54-60.

Utsumi, S A; Cibils, A F; Estell, R E; Baker, T T and Walker, J W (2010). One-seed juniper sapling use by goats in relation to stocking density and mixed grazing with sheep. Rangel. Ecol. Manag., 63(3): 373386.

Van Bruggen, A H C; He, M M; Shin, K; Mai, V; Jeong, K C; Finckh, M R and Morris, J G Jr (2018). Environmental and health effects of the herbicide glyphosate. Sci. Total Environ., 616-617: 255-268. 
Vijay, V; Pimm, S L; Jenkins, C N and Smith, S J (2016). The impacts of oil palm on recent deforestation and biodiversity loss. PLOS ONE, 11(7): e0159668.

Walker, J W (1994). Multispecies grazing: The ecological advantage. Sheep Res. J., Special Issue: 5264.

Weisenburger, D D (1993). Human health effects of agrichemical use. Hum. Pathol., 24(6): 571-576.

Wibawa, W; Mohamad, R; Omar, D and Juraimi, A S (2007). Less hazardous alternative herbicides to control weeds in immature oil palm. Weed Biol. Manag., 7(4): 242-247.

Wibawa, W; Mohamad, R; Juraimi, A S; Omar, D; Mohayidin, M G and Begum, M (2009). Weed control efficacy and short term weed dynamic impact of three non-selective herbicides in immature oil palm plantation. Int. J. Agric. Biol., 11(2): 145-150.

Wibawa, W; Mohayidin, M G; Mohamad, R B; Juraimi, A S and Omar, D (2010). Efficacy and costeffectiveness of three broad-spectrum herbicides to control weeds in immature oil palm plantation. Pertanika J. Trop. Agri. Sci., 33(2): 233-241.

Zaller, J G; Weber, M; Maderthaner, M; Gruber, E; Takács, E; Mörtl, M; Klátyik, S; Győri, J; Römbke, J; Leisch, F; Spangl, B and Székács, A (2021). Effects of glyphosate-based herbicides and their active ingredients on earthworms, water infiltration and glyphosate leaching are influenced by soil properties. Environ. Sci. Eur., 33(1): 1-16.

Zhao, X H; Zhang, T; Xu, M and Yao, J H (2014). Effects of physically effective fibre on chewing activity, ruminal fermentation, and digestibility in goats. J. Anim. Sci., 89: 501-509. 